\title{
下䫓骨に発生した軟骨肉腫の電子顕微鏡的研究
}

\author{
本間隆義・伊藤信明・遠藤隼人
}

\section{An electron microscopic study of chondrosarcoma of the mandible}

\author{
Takayoshi Honma - Nobuaki Ito - Hayato Endo
}

腥

言

輅骨肉連が頻骨飞発生することは，きわめて稀である とされている12233).

軟骨肉腫は未熟な軟骨性組織の增殖から成り，基質で ある㰸骨組織に大小不同の軟骨細胞が散在するのが基本 的組織像であるが, Myxomatous change p Cystic degeneration あるいは Fibrosarcomatous change または 石肉化などの所見の認められることが稀ではないか．軟 骨肉瘇の診断にあたっては，組織学的に良性の軟骨腫性 病変と，または骨原性肉連との区別がしばしば問題にな ることが多い66). この場合，良性の軟骨腫性病变との 判別基準としては，膨大した核をもった軟骨細胞が多数 存在すること，このような核を 2 個有する細胞がかなり あること，大きな核が個あるいは数個の核をるった。 または港染するクロマチンに富んだ巨大軟骨細胞が存在 することなどがあげられて扮り7，また，骨原性肉腫と の判別については，腫瘍細胞が直接未熟な骨質（オステ オイド）形成している像がみられる場合には，軟骨組 伡の有無に関係なく骨原性肉腫と定義することによっ てて89)，一往は明確に区別がされている.

一方, 軟骨肉腫を肉腫たらしめる腫渲細胞の微細構造 を中心個々の腫煌細胞相互間の関連性については, 汪とんぞ考虑されていない現状である。

著者らは，下頻に発生したきわめて稀な軟骨肉腫の 1 例を経験したので，その臨床的概要を詳述し，軟骨肉腫 を特徽づるところの典型的な軟骨性分化を示す厘瘍細 :胞を電子顕微鏡的に観察し，興味ある知見を得たので報 告する.

\section{症例}

\section{患 者 : 27歳の女性}

岩手医科大学齿学部口腔外科学第 1 講座

（主任：藤岡幸雄教授）

First Department of Oral Surgery, School of Dentistry, Iwate Medical College (Chief : Prof. Yukio Fujioka) 受付 : 昭和 51 年 7 月 18 日
初 診: 炤和 49 年 6 月

主 訴: 下顎正中部の腫脹

家族歴：特記すべきことなし

既往歴：2 歳時にオトガイ下部を切開したといら（原 因不詳). 17 歳時に交通事故にてオトガイ部を打撲した とい5.

現病歴: 約 8 カ月前より下顎正中部の唇側歯肉に小指 頭大の硬い膨隆のあることに気付き, 疼痛のないためそ のまま放着するる，漸次拇指頭大にまで增大するため某 歯科にて摘出手術をらける. その後, 1 カ月程して再び 同部に無痛性の腫脹を認めるようになったため，当科に 紹介された。

現症：全身所見：体格中等度，栄盖良好。

口腔外所見：顔貌は下口唇部よりオトガイ部下縁にお。 よぶ $4.5 \times 4.5 \mathrm{~cm}$ 大の比較的境界不明瞭な半球状の尰 脹があり；皮淢は異常なく正常色で可動性にて下部の膨 隆とは撚着はなく，無痛性である（写真 1). 買下りン パ節は左右ともに米粒大の腫大を認め, 可動性で圧痛は ない. 頸部りンパ節は触知されない。

口腔内所見 : $\overline{3+3}$ 部の唇側䤴肉より歯肉唇移行部に

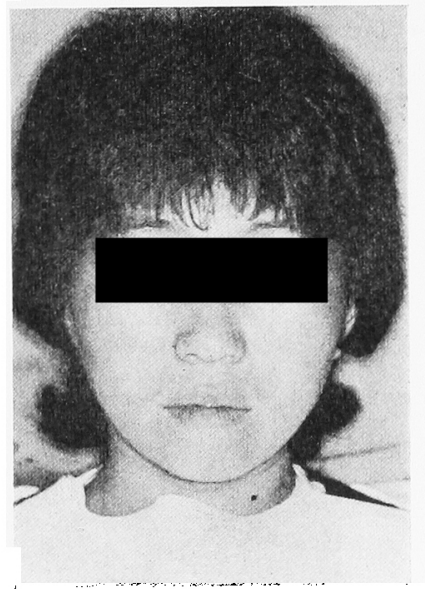

写真 1 正面顔貌 
$2.0 \times 2.5 \mathrm{~cm}$ 大の境界明瞭な半球状の腫瘤を認め, 被覆 粘膜表面は異常なくほとんど正常色にて, 硬度は弾性硬 であり，圧痛はない， 21 は中等度の動摇がみられ，ま た， 2 | は遠心に圧排されているため, $\overline{21}$ 部で約 $4 \mathrm{~mm}$ の歯間離開を認める (写真 2). 電気生活 歯骾診では $\overline{3+3}$ ともに反応を認める.

臨床検査所見：一過性の尿蛋白の出現をみるほか, と くに異常值は認められない（図１）。

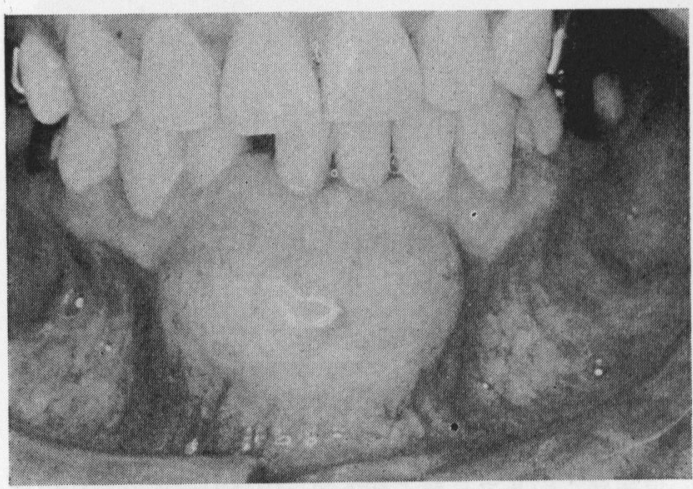

写真 2 下顎正中部の腫瘤

レ線所見 : 膨隆相当部は全体に淡い不透過像を示し (写真 3 ), $\overline{21}$ の歯間部では僅少に濃淡像が認められる. また, $\overline{21}$ 部の歯槽突起部では骨梁の乱れ消失があり限 局性の骨破壊像が認められる. 腫瘤部の歯根の吸収所見 は認められないが， $2 \mid$ の硬固板は消失し，歯根膜腔の 開大が認められる（写真 4)。 また，腫瘤に隣接する顎

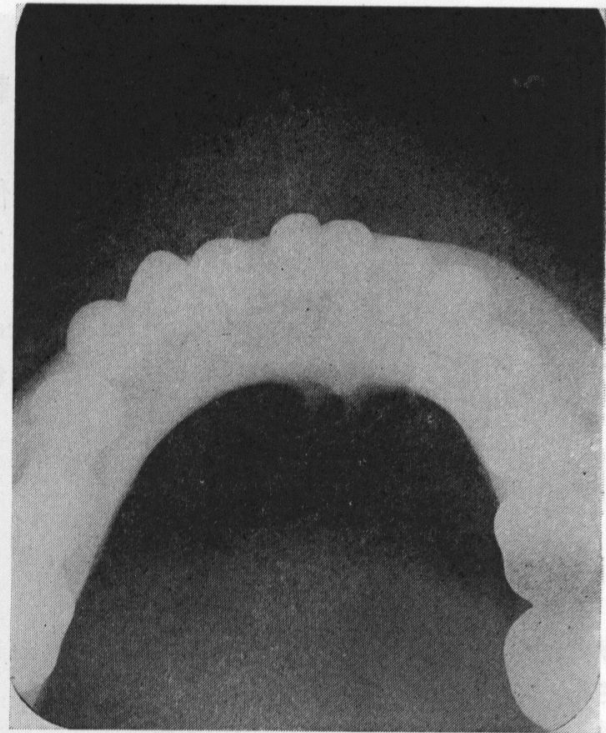

写真 3 膨隆相当部の淡い不透迥像

骨皮質は軽度の吸収が認められる。

病理組織学的診断：試験切除標本拈よび手術摘出物の 全割標本から, 本学歯学部口腔病理学教室にて軟骨肉腫 の診断を得た。

処置および経過：術前に放射線療法として電子線 3,000 rads 照射した後，全身麻酔下において，オトガイ 下部下頡骨下縁にそって約 $10 \mathrm{~cm}$ の切開を加え，口腔 内は $\overline{6 \uparrow 6}$ 歯槽部に横切開を加え, 口腔内外より䟝離

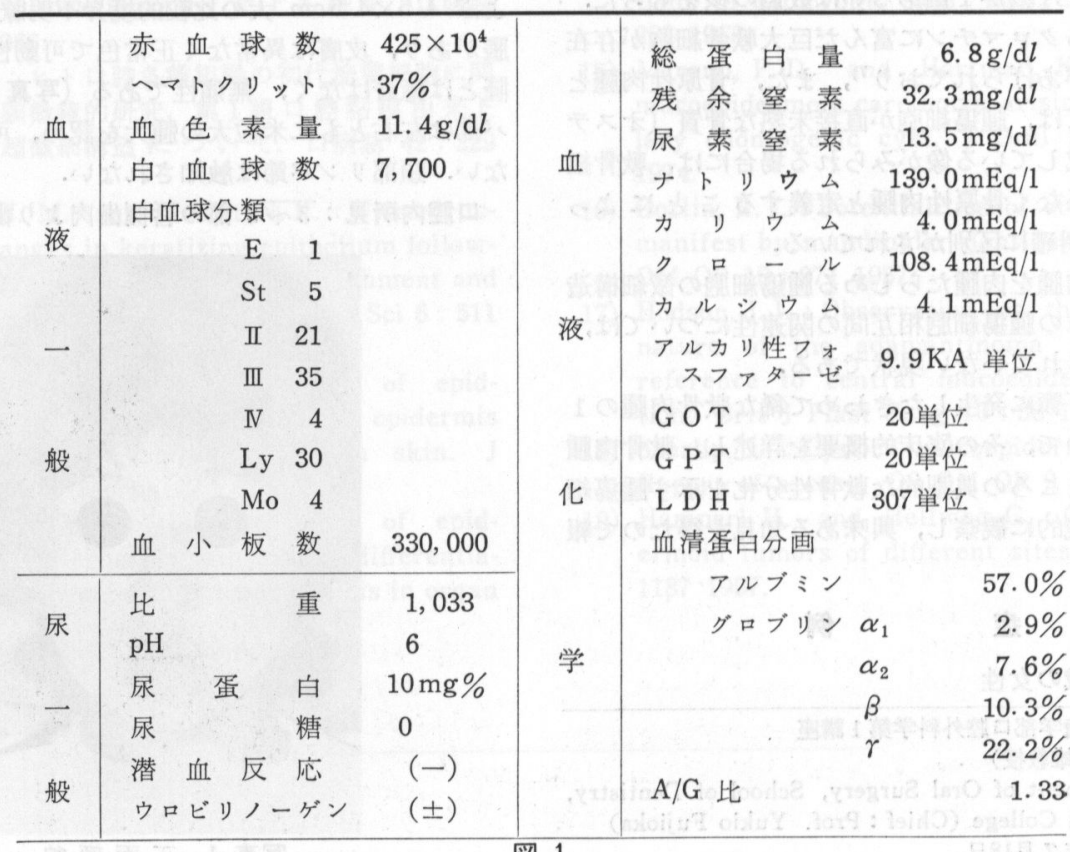




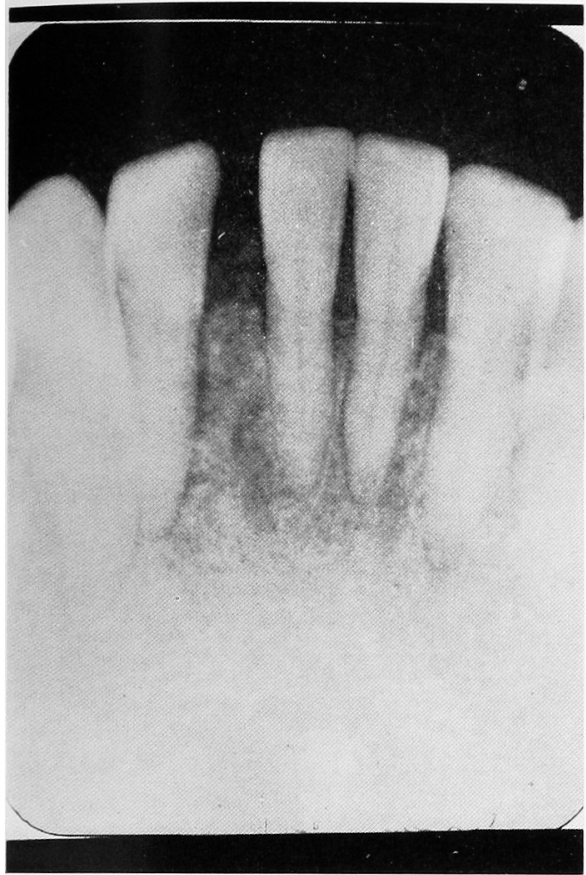

写真 4 歯楱突起部の限局性の骨破墙

して下顎骨を露出し，腫瘍ならびにその周囲の靧骨を $\overline{6 \mid 6}$ 部より離断した（写真 5 )。な执，腫瘤は $\overline{3}+3$ 部 で周囲軟組織とは境界明睹で瘉着なく容易に䟝淮できた。 衍後的 2 年を経過するが, 再発転移の题候は認められず, 現在慎重に長期経過観察中である.

光学顕微鏡的所見：生検材料のエポン包埋による厚切 切片のトルイジン・ブルー染色では, 軟骨様細胞は罪型
性があり，大きさは大小不同が見られ，形態およびその 配列はきわめて不規則である。腄瘍紐胞の核は膨大し 1 個のものが多いが，膨大した 2 個の核を有する細胞も認 められる。また，細胞周困には明調帯が見られ未熟な軟 骨を形成している（写真6）.

電子顕微鏡的所見：軟骨肉腫細胞は各種形態を示す細 胞が混合し，きわめて多彩性に富んでいるため，その特徴 をとらえて共通所見として記载することは非常に困雉な ことではあるが，本腫瘍を楧成する稩胞をその核の数に 上って，1）単核腫瘍細胞，2） 2 核腫瘍細胞，3）分 葉または多核腫瘍細胞の3 型に分類し，そのおのおのに ついて, 細胞全体の形態, 核の形態, 細胞質内小器官の 形態なとについて詳細に検討する. そして最後に，本腫 瘍を構成する細胞の崩壤像を記載する。

\section{1) 単核腫瘍細胞}

腫瘍組織を满成する単核紐胞は，核は細胞質に比して 一般に大きく，丹形（写真 7) や鎌状形（写真10）ない し長棈円形（写真 9）で，細胞の处形はほぼ核形に一致 し，Microvilli よ5の細胞質突起が認められる，核膜は 比較的平滑であるが，長楕円形のものでは軽度に凹凸不 整が認められる。核の立体像としては球形状を呈 しているが，核の内方に向かって深いかつ複雑な陷凹が 見られるために，核の分葉化が類推されたり（写真12）， 長楕円形の核でその中央部が強くくびれるために，核の 2 分化が類推される細胞も認められる(写真13). 核質 はほぼ Euchromatinによって占められており，Heterochromatin は核膜にそって僅少にしか認められないが， ときには細胞の変性に伴って核内にまだら状に出現する ことがある（写真10），また，核内にはInterchromatin granule が集塊をなして認められる．核小体は通常 1 個

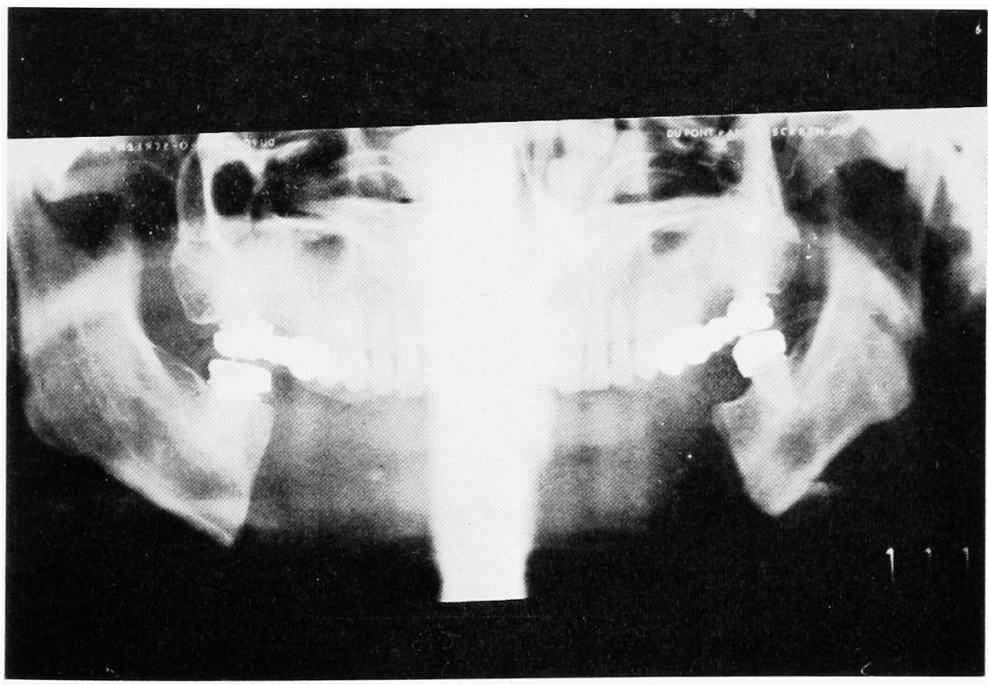

写真 5 下罘骨連続離断後のレ線像 


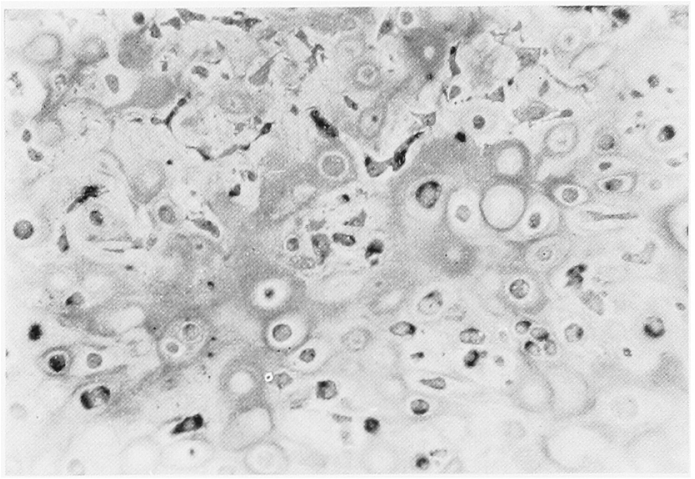

写真 6 トルイシン・ブルー染色による光顕像

認められる，細胞質内には長管状の粗面小胞体が認めら れ，乙ばしば整胞状に抬張し，内容物として綿毛状の電 一密な物質を渚溜するほか多数の险細顆粒を含んでいる. 粗面小胞体の高度の膨大拡張のために, その内部に細胞 質が細片化して島嶼状に浮ぶことがあり（写真 8)，ま た細胞膜を破綻せしめたり（写真 11），細胞質全体を膨 化せしめてついには細胞を変性に至らしめる（写真10）. Mitochondria は小型で電子密な物質を入れている. Golgi 装置の発達は一般にわるく萎縮状であることが多 い.ときには Golgi 装置は膨化し, 膨大した Golgi 空 胞がその内腔に粗面小胞体の内部に認められるものと同 一の綿毛状の棈造物を入れて多数認められることがある. 膨大した Golgi 空胞は細胞膜周辺に蝟集し, その内容 物を細胞外に流出している（写真10），そのほか細胞質

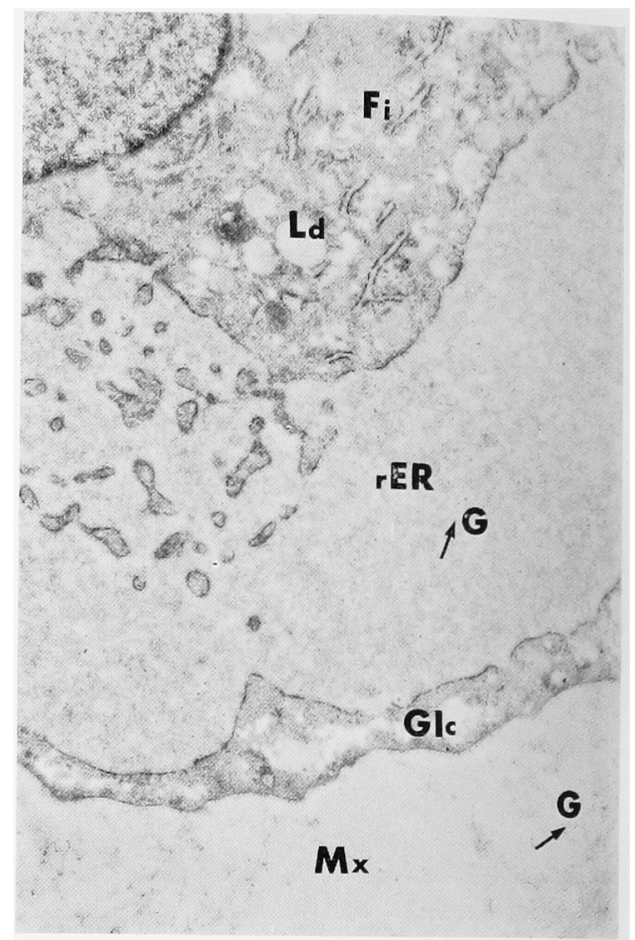

写真 8 単核腫㾤細胞の細胞質, $\mathrm{rER}$ (粗面小 胞体）が膨大搪張し，その内部と $\mathrm{Mx}$ (基質) $K G$ (微細顆粒) をみる， Fi (細線維)， Ld (脂肪滴)，13,400倍.

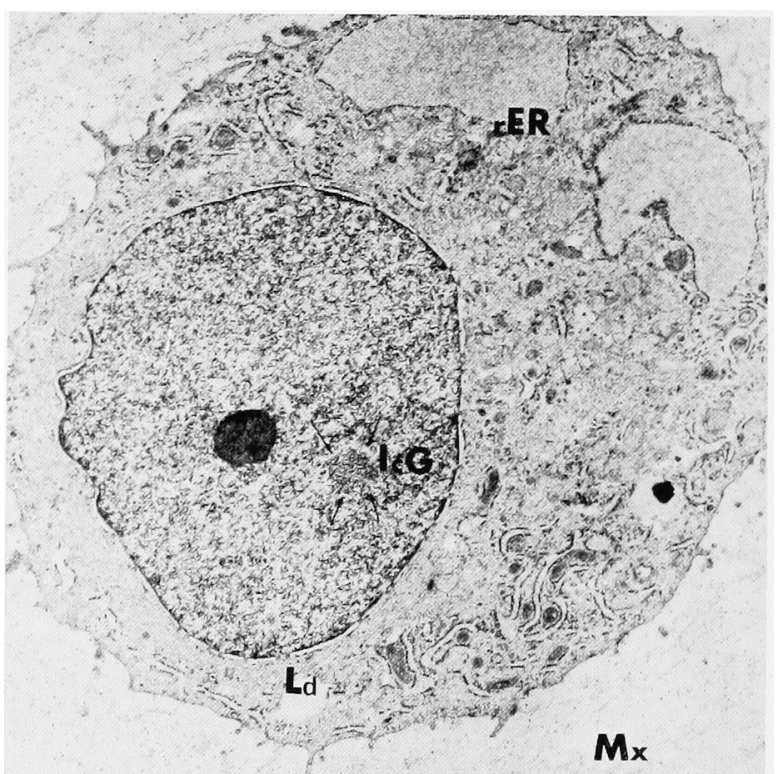

写真 7 単核腫煌細胞，核は類円形である，ICG (interchromatin granule), rER (粗面小胞体) の拡張， Ld (脂肪滴)， Mx （基望），980倍. 


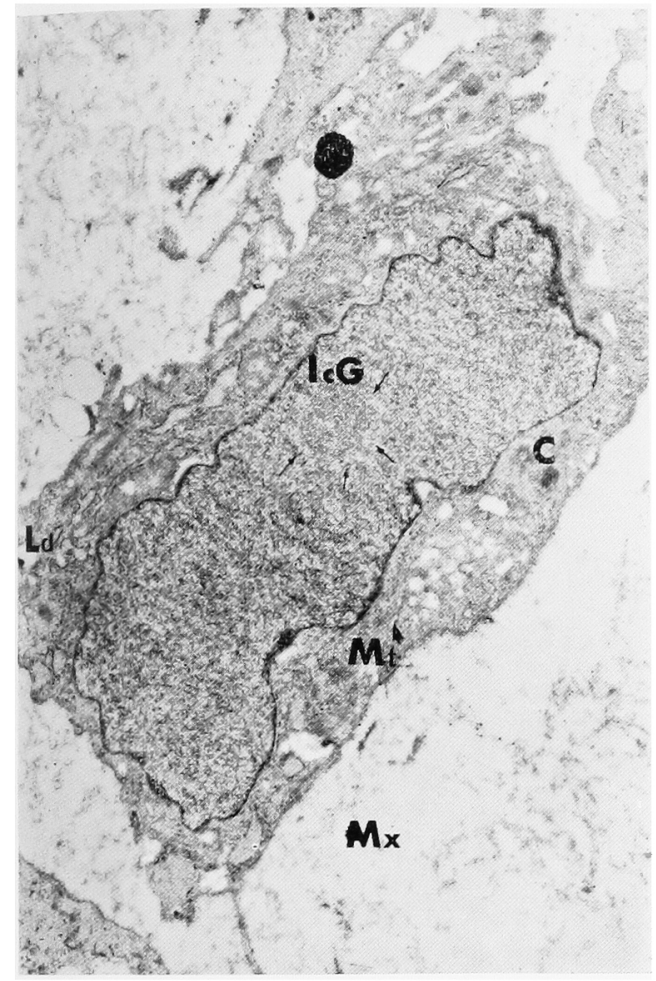

写真 9 単核腫傷細胞，核は長棈円形である， 細胞同志は近接し長大な突起を出す, IcG (interchromatin granule), $\mathrm{C}$ (中 心子)，Mt (微細小管)， Ld (脂肪滴)， $\mathrm{Mx}$ (基質)，10,000倍.

内には，微細な細線維が走向し交錯して広く分布してい る. また，均質性の Lipid droplet が細胞質内に平均 して数個宛認められる. Glycogen の細胞質内沈着につ いては，電子密度の低い均質無權造な領域として認めら れるが，量的な增減に関しては単核腫瘍細胞個々につい てはとくに一定した傾向は認められず，ほとんど認めら れないこともあり，または散在性であったり，ときた は粗面小胞体の比較的少ない細胞質内に比較的多量の Glycogen が沈着していることもある.

基質については，一般に細胞周辺は低電子密度の均質 性であり，膨化した粗面小胞体内に認められるものと同 一の綿毛状の物質や微細顆粒がびまん状に散在するほか， 無周期性の細線維が眯に走向しており，ときには非常に 密に走向し交錯してCapsule を形成していることるある. 上記単核腫湯細胞のほかに単核細胞としては，細胞全 体の形態が細長くかつ紡錗形で，細胞膜とコラーゲン線 維が密な関連を窥わせる線維芽細胞ないし線維細胞が認 められる.

\section{2) 2 核腫瘍細胞}

隀瘍組織を搆成する 2 核の腫瘍細胞の外形は円形ない

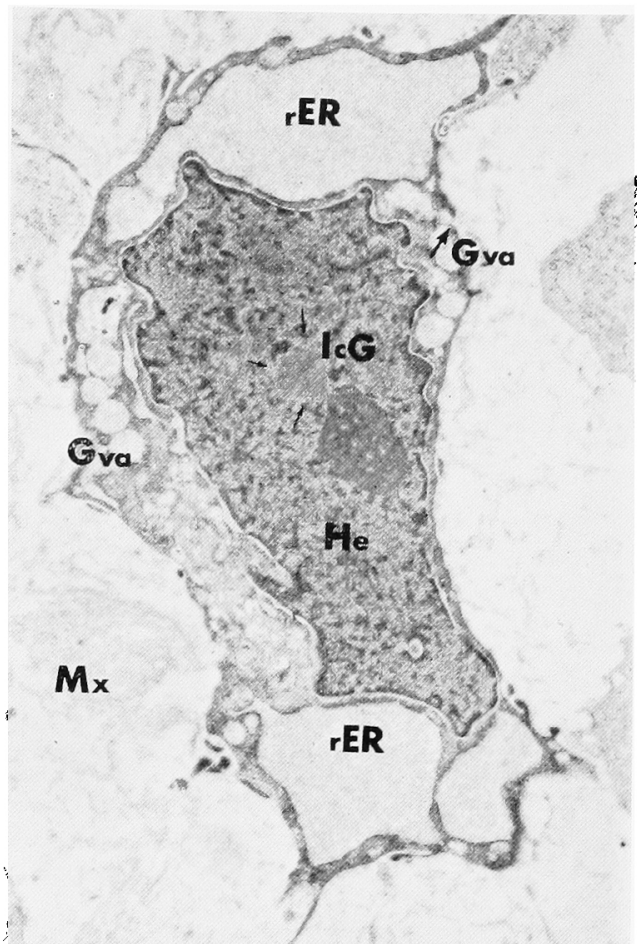

写真 10 単核腫瑝細胞，核は鎌状形である， He (heterochromatin), IcG (interchromatin granule), rER (粗 面 小胞体) の膨大拉張と Golgi 装置 の萎縮, Gva (Golgi 空胞) の膨化, $\mathrm{Mx}$ (基質)，10，000倍.

し楕円形で，核は細胞蛬に比してきわめて大きくなり， 2つの核はほぼ同形で円形ないし椿円形をしており，細 胞質の片側に位置して相㫼りあっている（写真 14）。核 膜はほぼ平滑で，一方の核には軽度の陥凹の諗められる ことがある、核質は Heterochromatin がほとんど羿め られないために明るい，また明瞭な核小体が認められる.

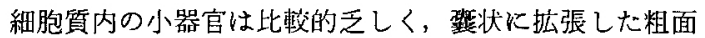
小胞体が細胞質の周辺をらめるがごとくに認められ，そ の内部には綿毛状の構造物や政細顆粒とともに電子密な 物質を猪溜している. Mitochondria や Golgi 装置の 発達はいずれもわるくほとんど羿められないことが多い。 そのほか細胞質内には，僅少の凯細な細線維と数個の Lipid droplet が認められる. Glycogen の細胞質内へ の沈着はほとんど悥められないことるある。

基質については，細胞周辺は低電子密度で均質性であ り，棉毛状の蛪造物や微細顆粒がびまん状に散在するが， 無周期恻:の細線維は一般に僅少である.

3）分葉状または多核腫瘍細胞

腫瘍組織を棈成する分葉状の腫埸細胞は，巨大な核が 深い切れ込みや高度の凹凸不整をるつために，1 枚の切 


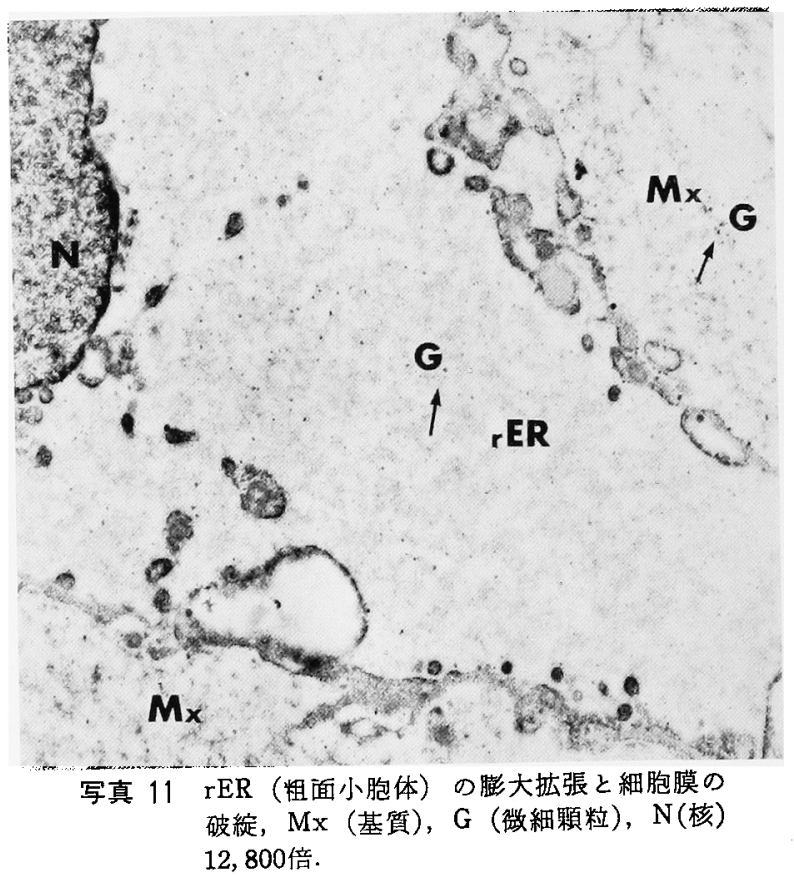

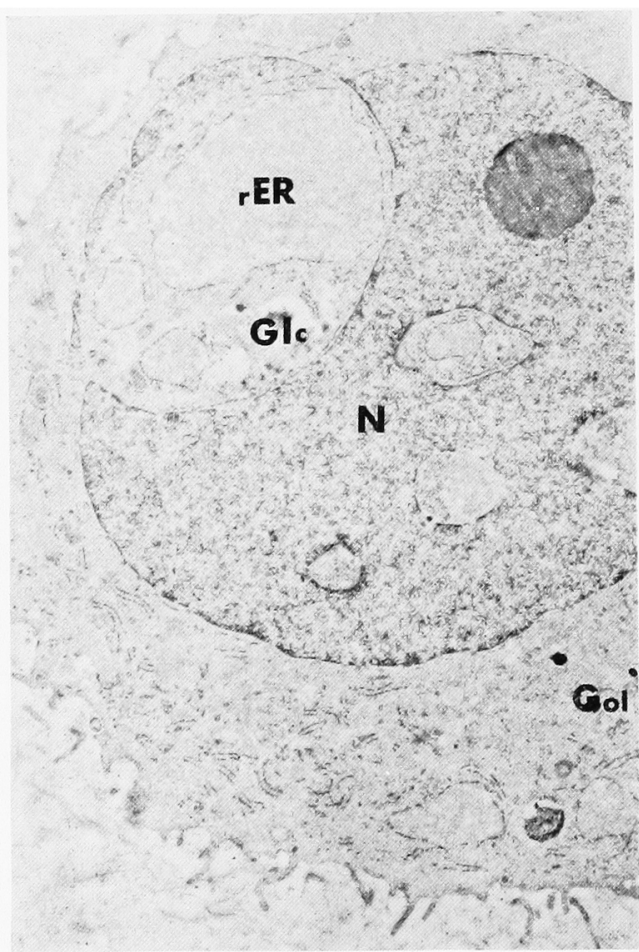

写真 12 単核腫㴻細胞, N(核) の不規則化， $\mathrm{rER}$ (粗面小胞体) の拡張々 $\mathrm{Gol}(\mathrm{Go}$ lgi 装置) の荌縮, Glc (ク゚リコーゲ ン) の沈着, 10,000 倍.

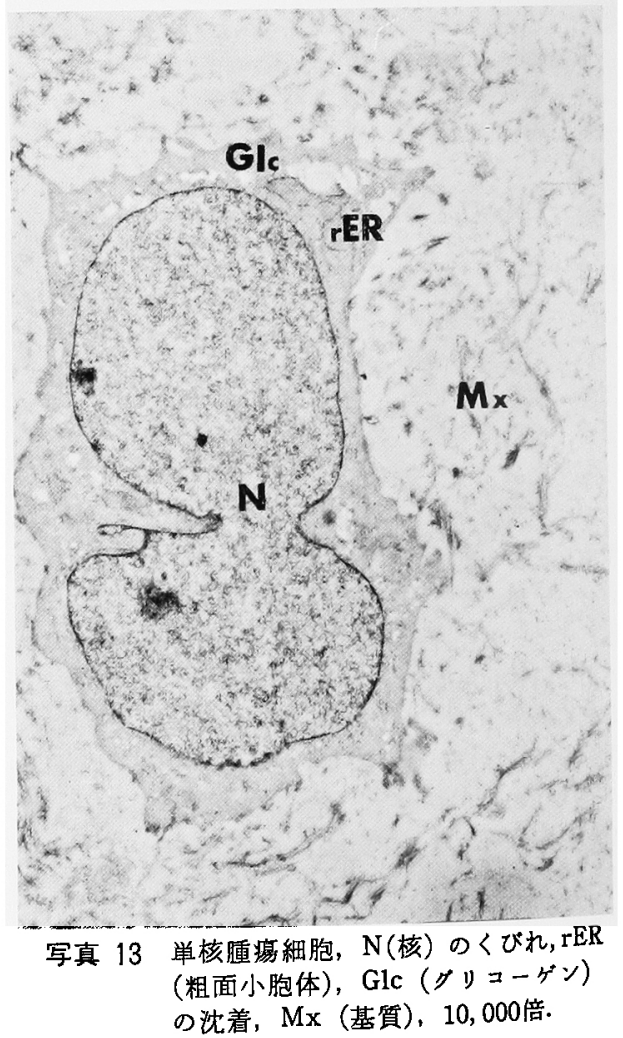




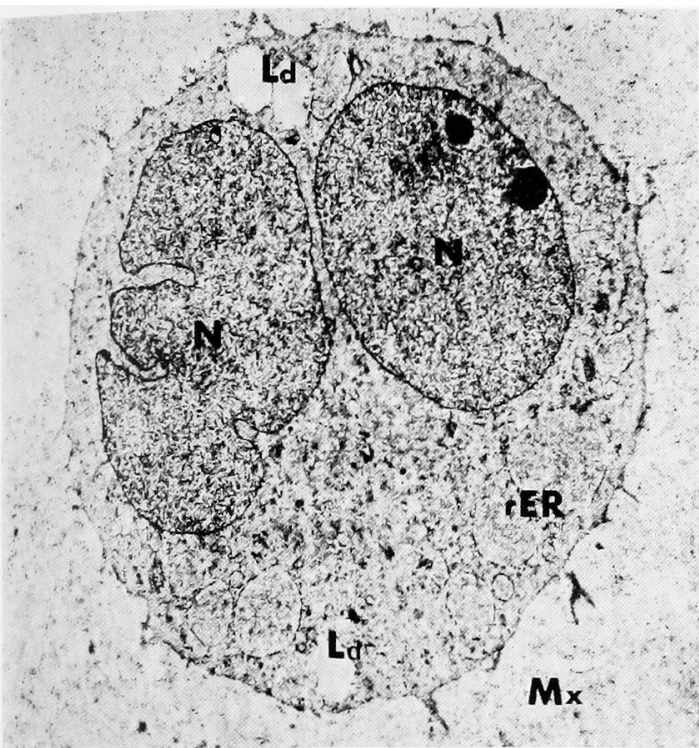

写真 14 二核腫瘍細胞, 注同一大の 2 個の

$\mathrm{N}$ (核)，rER (粗面小胞体)， Ld(脂 肪滴）， $\mathrm{Mx}$ (基質)，5,600倍.

片上に表現される核の数は切断されて観察される結果, 少なくとも 2 個以上に独立的に存在して認められること が多く，巨大な凹凸不整のある 1 つの核と数個の小型の 核断面がほぼ細胞質の中央に位置して一群となって認め られる（写真 15）。一方，多核の腫瘍細胞は，数個の円 形ないし楕円形をしたほぼ同型の核が主として細胞質周 辺に環状に排列して認められることがある（写真 16）.
しかし，上記の観察したような核の分葉状と多核との明 確な区分を行えることはまれであり，両者の区分はたぶ んに恣意的な要素が入ることはさけられなく，単に巨核 の切片状の一断面における表現上の相望にすぎい可能 性は否定できない。分葉状または多核腫瘍細胞の核質に ついては, Heterochromatin は核膜にそって僅少に認 められるが，細胞質の濃縮変性に伴って核内全体にびま ん状に增加して認められることがある。核小体はときに は1つの巨大核に数個認められる。細胞質内の小器官に ついては, 粗面小胞体はつよい濃縮変性の諗められる緗 胞質内では比較的小型で少ないが，一般に壁胞状に抬張 したものが多く認められ，その内部には綿毛状の構造物 や政細顆粒とともに電子密な物質が塔溜し，ときには細 胞質の一部が細片状となり島嶼状に浮ぶことがある（写 真16). Mitochondria は円形小型のものが多く，その基 質は高電子密である，Golgi 装置は発達はわるく萎縮状 であることが多く，ときには痕跡状のるのが認められる. その汪か細胞質内には，Microtubulus や，僅少の微細 な細線維が走向し交錯していることがある. Glycogen の細胞質内沈着については，電子密度の低い均質無構造 な領域として認められるが，その量的な出現については とくに一定した所見は認められない.

基質については，1）2）で記載した所見とほぼ同一で ある.

\section{4）腫瘍細胞の崩罜について}

軟骨様基質中に，細胞の崩壊遺物としての細胞膜様の 細片や細胞質の一部と思われるるののほか，核や細胞質 内小器官と思われる高電子密度の塊状物や顆粒状物など

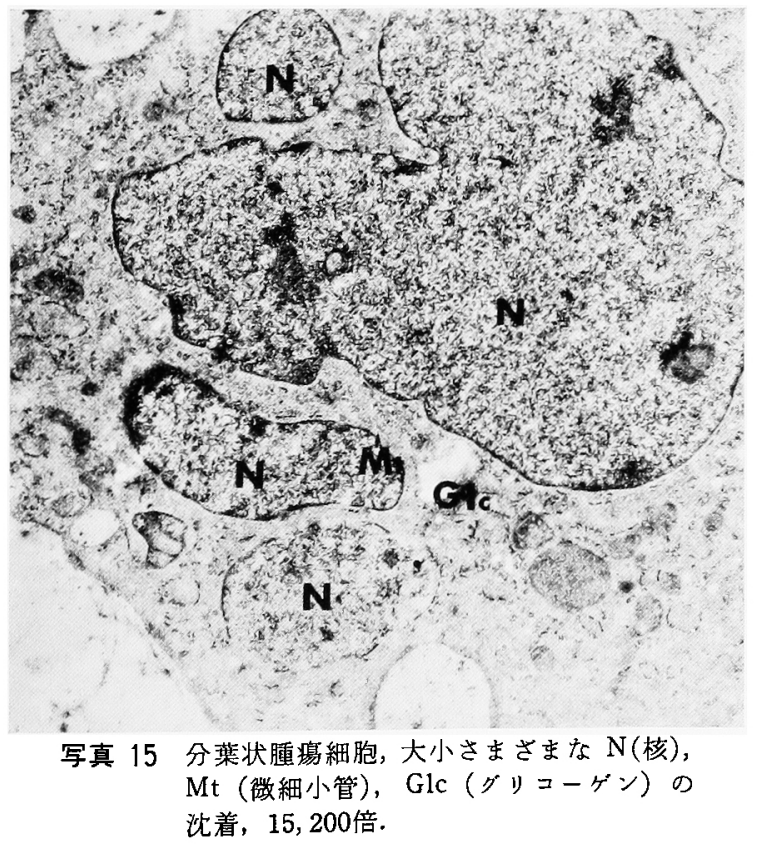




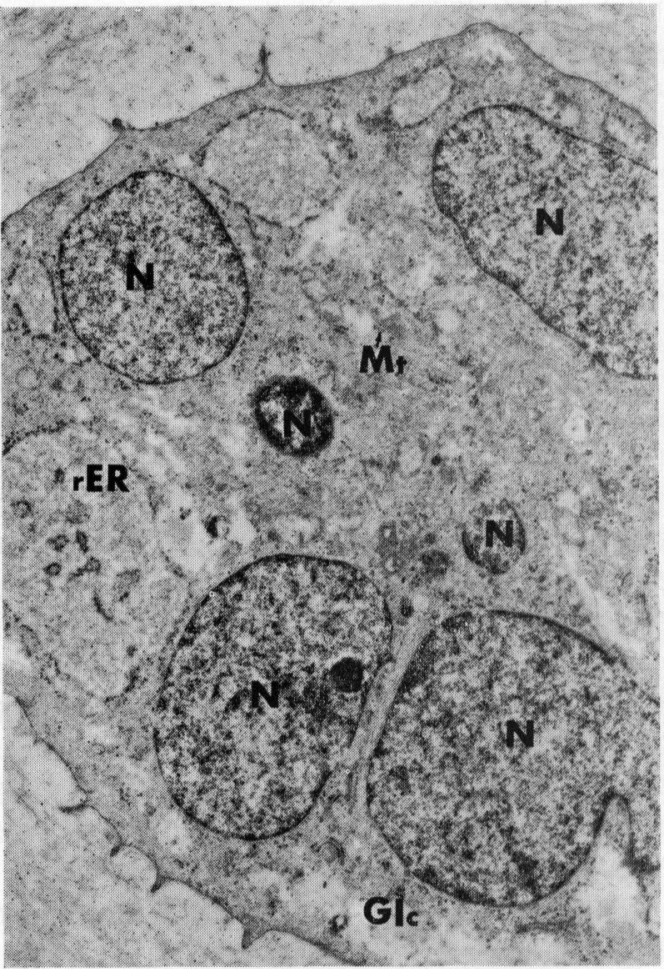

写真 16 多核腫瘍細胞, 細胞質周辺にほぼ同 一大の N (核) の配置, rER (粗面 小胞体) の拡張, $\mathrm{Mt}$ (微細小管), Glc （グリコーゲン）の沈着, 10,000倍.
が認められる（写真 17）。またこのような細胞破片を 囲繞するように無周期性の細線維が密に入り込んで錯走 していたり（写真17），ときには細胞の破片が綿毛状の 構造物や微細顆粒とともに細線維の密集する基質中に認 められることがある.

\section{考察}

軟骨肉腫の起源については, もともと軟骨系細胞の存 在する部位，あるいは軟骨を形成する未分化な間葉細胞 の存在する部位などから発生することが多いといわれ る. 下顎では胎生期に筋突起, 関節突起㘧よび中切歯の 部に軟骨の存在が認められることにより, 本症例におい てもその遺残軟骨よりの発生の可能珄が示唆される

一般に，癌細胞はいずれの組織から発生したものも， それぞれの母細胞に特別に発達して母細胞を特徴づけて いた構造の発達が負となり，すなわち脱分化がおきるか゚， たとえ未分化癌であっても完全に分化能を失い特異構造 を欠いていることはなく，不完全な形でときには痕跡的 に, 細胞ごとに種々な程度に分化が認められる．軟骨肉 腫に打いても, 分化の過程がその成熟したものにあって は，母細胞と対比して細胞および基質ともに典型的な形 態を認めることができる。このような観点から，軟骨肉 腫細胞の電子顕微鏡的研究は, 正常の母細胞群あるいは 異種病変に陉った同系統の細胞群との対比のうえにたっ

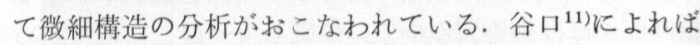
軟骨肉腫細胞を，1）正常成熟軟骨に類似したC 型細胞, 2）正常軟骨組織にあって Perichondrium，または線 維軟骨における Perichondrocyte または Fibrocyte に

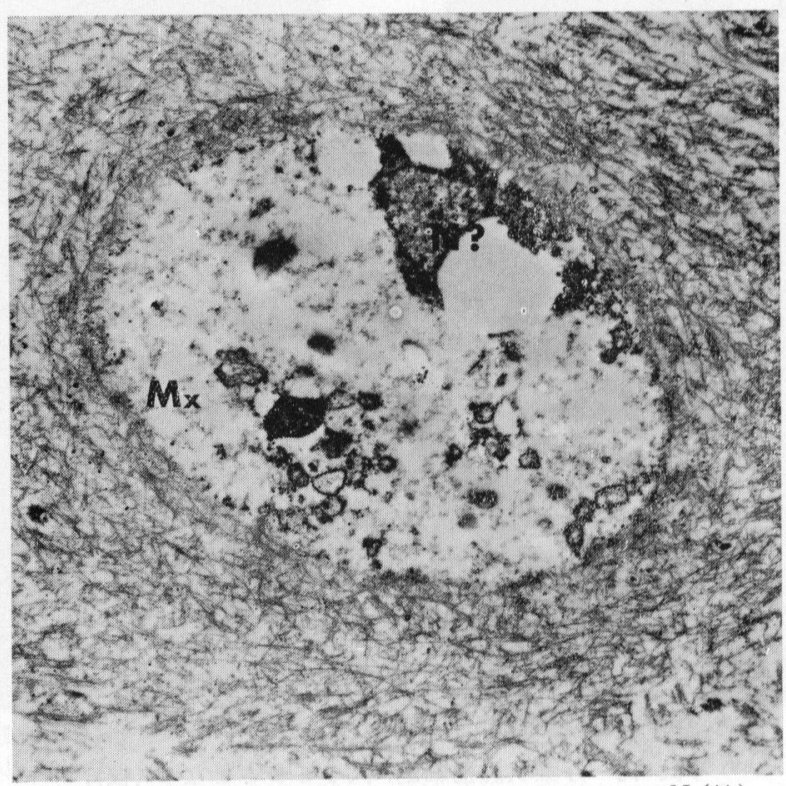

写真 $17 \mathrm{Mx}$ (基質) 中飞細胞の破片が散在する, $\mathrm{N}$ (核) と思われる高電子密度の塊状物, 7,000倍. 
類似を求める $\mathrm{F}$ 型細胞，3）正常軟骨組織および良性軟 骨腫組織中には比較検討の対照をもたないM型細胞，以 上の 3 型に分類し，軟骨肉腫細胞がもつ多分化能を超微 構造上に認めている. 一方，軟骨肉腫を構成する個々の 複雜多様な腫瘍細胞の相互関係については, Erlandson と Huvos ${ }^{12)}$ は, 各種の軟骨肉腫病変を電子顕微鏡的に 観察し，正常軟骨細胞に近い形態をとるものと，ク口マ チンの形態的変化と核小体の数の增加があって, 粗面小 胞体の縮小と Glycogen 顆粒の減少および脂肪滴と細 胞質内細線維の增加するものを，組織学的分類を基にし て比較検討を行っている. また，井村と田中 ${ }^{13)}$ は，組織 学的に軟骨肉腫を未分化型と分化型に分類し，両者の腫 湯細胞について電子顕微鏡的に観察し，未分化 型では 核・細胞質比および核不規則性指数ともに高値を示し有 意差があると報告している。

軟骨肉腫を肉腫たらしめている腫瘍細胞の特改の 1 つ として，核の膨大および不規則多様性にあることは諸家 の一致して認める見解である．著者らは光顕的に膨大し た核や2核および多核の軟骨肉腫細胞を確認し，さらに これらの腫場細胞を電子顕微鏡的に観察したものである が, 単核の腫瘍細胞では核の形態の外形は円形ないし鎌 状形を呈するものの，その核膜はかならずしも円滑でな いことがあり，ときには核の内方に向かって複雑な切れ 込みが認められ，また，楕円形を呈する核のほほ中央部 で強いくびれの認められるものがある．このような所見 は，母細胞に核の形態がきわめて類似した単核のものが， 軟骨肉腫病変の悪性度を左右する 2 核ないし分葉または 多核のものへ移行のあることの左証と考えられる。

軟骨肉腫細胞の細胞質内小器官については，著者らが 観察した光影的に Chondroid formation のある部位で の軟骨肉腫細胞では, 粗面小胞体の膨大払張の傾向のあ ることと，Golgi 装置の萎縮はほほ共通した所見として

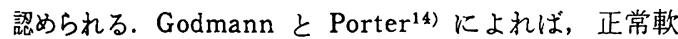
骨細胞が分化し分泌機能を開始するよらになると，粗面 小胞体の著明な拡張および量的増加と Golgi 装置の著 明な発達が認められるとし，また，Golgi 装置の領域で は平滑な限界膜で包まれた Golgi 空胞が次第に生長し， この空胞は細胞表面に移動し，限界膜が細胞膜に瘉合す ることによってその内容を細胞外に放出するという．こ の Golgi 空胞の内腔には著者らも観察しているように綿 毛状の構造物と，軟骨基質に执いて認められるコンドロ イチン硫酸とタンパク質を含む粘液多糖類と考えられて いる顆粒構造 ${ }^{15}$ によく似た微細顆粒が認められている. 著者らが観察した栾状に拡張した粗面小胞体の内部には, Golgi 空胞や基質において認められるものと同一形態を した微細顆粒が多数認められた．軟骨肉腫細胞では GoIgi 装置の認められることが少ないこと，またしばしば 萎縮状であることは，粗面小胞体で合成されたタンパク 質の Golgi 装置への転送が行われても，タンパク質の
合成能力が Golgi 装置の処理能力を上まわるため, Golgi 装置は膨化状となりついにはその機能が停止し退縮して しまうことによるのであろう。しかし，粗面小胞体での タンパク質の合成はとどまるところがなく，そのため粗 面小胞体の膨大拡張がいっそう助長されてゆくるのと考 えられる、なお，円形ないし镰状形の単核腫瘍細胞の粗 面小胞体は，長大楕円形の単核腫湯細胞之比較すると， その膨大拡張はより強い傾向がみられるが，前者にあっ ては，細胞周辺の基質は綿毛状の榄造物や無周期性の細 線維が密であることが少なくないことから，粗面小胞体 の膨大抎張の程度は腫瘍細胞間の機能的な相違の反映さ れることも考虑されるべきであろら，また，微細顆粒に ついては，その生成機序において，Golgi 装置が関与す ると考えられているが ${ }^{14)}$, 軟骨肉腫細胞では粗面小胞体 での閉塞性濃縮の過程で析出しており，その生化学的な 構成成分などの比較検討については今後の研究にまたね ばならない。

軟骨細胞の細胞質内で認められる Glycogen につい ては，酢酸ウラニール・クエン酸鉛で二重電子染色を行 った電子顕微鏡像では電子密度の高い小顆粒として認め られるが(6)，ときには電子密度の低い均質無構造な領域

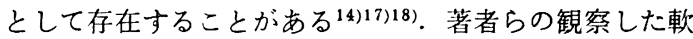
骨肉腫細胞の細胞質内に沈着した Glycogen も後者の 所見であった. 軟骨肉腫の Glycogen の消長に関して は，悪性度に関係するといわれており，Glycogen の多 いほと Low grade Malignancy といわれ，少ないもの はそれたけェネルギー源として利用されるために High grade malignancy と考えられている. しかしながら，

著者らが観察した範囲では軟骨肉腫細胞の細胞質内 Glycogen の沈着については, 個々の細胞について非常 にバラッキがあり，細胞の形態によってもとくに一定し た傾向を把握することはできなかった，それゆえ，むし ろ Glycogen の消長の意味するところは，その細胞の ある時期における機能の種々な状態を偶然にとどめてい るにすきないものと考えられる。

軟骨肉腫細胞の細胞質内に出現する細線維については, 著者らの観察では，核の形態分類とは関連性はなく，細 胞質全体を埋めるがごとくに粗面小胞体が膨大抎張し ている場合には比較的多量にみられ，細胞質内に多量の Glycogen が沈着し一見細胞質全体が無構造化している ような場合には少ない傾向が認められる。しかし，細胞 質全体が濃縮状を呈している場合には細線維の存在は判 然としなくなることが多い，細胞質内細線維はとくに変 性ないし崩壊状態にある軟骨細胞で多く観察されるとい う報告 ${ }^{18)}$ あるが，軟骨肉腫細胞においては，変性の敳 候を示すものであろらが，なんらかの粗面小胞体の膨大 扗張との関連を窥わせるものである.

軟骨肉腫細胞が崩壞するにあたって, 谷口 ${ }^{11}$ は, 細胞 質内に一重の限界膜に境された微細な Lamellar な構造 
を有する小器官を“Lysosome” と考えて報告している が，著者らの観察した変性している軟骨肉腫細胞におい ては Primary lysosome と考えられる所見は認められ なかった. Silberberg ら ${ }^{17}$ は, 軟骨細胞が老化すると, 細胞質は小器官が退縮するとともに Glycogen と Lipid が增加し, ついには核および細胞質が濃縮状となって膨 化がおこり細胞は崩壊するとし，また，生長ホルモンを 若いマウスに注射した実験20)では，粗面小胞体や Golgi 装置などが急速に発達増加した後，早期に萎縮状となり， ついにはやはり細胞の膨化がおこり崩壊し, 基質中に軟 骨細胞の大きさの電子密度の高い塊状物質や，ときには 構造上それが核や破壊した細胞質と考えられる物質が認 められるよらになるといわれている ${ }^{19)}$. したがって，軟 骨肉腫細胞の崩壊は, 細胞の疲弊による細胞質内小器官 の退縮とそれにつつく濃縮変性過程が当然存在するすの と考えられるが，それ以外に，過度な粗面小胞体の膨大 桩張によるところが大きいと判断すべき所見が認められ た.すなわち，軟骨細胞は軟骨基質を形成する特殊な分 泌細胞であると解するならば, 粗面小胞体の膨大㧪張は 一般にタンパク質の旺盛な合成を形態的に示す共通性の 現象であると考えられるが，かならしずもその現象自体 が細胞の崩壊をまねくことは諸家によって指摘されてい ない. しかるに, 軟骨肉腫細胞においては分泌細胞とし ての分化を保持しているがゆえに，とどまるところのな いタンパク質の合成が行われ，それはまず Golgi 装置 の機能を麻痺させ，ついには細胞自体を破裂崩壊せしめ るすのと考えられる.

結

\section{論}

1. 著者らは27歳の女性で，下顎骨正中部に発生した きわめて稀な軟骨肉腫の 1 例を経験した.

2. 軟骨肉腫細胞を電子顕微鏡的に観察し, 核の形態 により単核， 2 核，分葉または多核の 3 型に分類した.

3. 観察しえた軟骨肉腫細胞では, 細胞質内小器官の らち粗面小胞体の膨大拡張と Golgi 装置の萎縮が共通し た所見として認められた.

4. 過度の粗面小胞体の膨大払張は, 軟骨·肉腫細胞を 崩壊せしめるものであると指摘することができた.

本論文の要旨は，第20回日本口証外科学会総会(1975) において発表した。

稿を終わるに際し，御校閲を頂いた藤岡幸堆教授に謝 意を表し，病理組学的所見について御教示を媔いた本 学蒾学部口腔病理学鈴木鍾美教授に深謝します。また， 電子顕磴鏡の資料作製にあたって御協力を頂いた丸山節 子氏に感謝します。
文

\section{献}

1) Chaudhry, A.P. et al. : Chondrogenic tumors of the jaws. Am J Surg 102: 4031961.

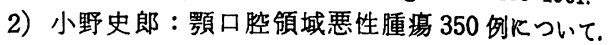
日口外誌 $5: 1021959$.

3）上野 正，他：わが教空における最近12年間の肉 腫の臨床統計的研究. 日口外誌 $6: 4171960$.

4) Arlen, M. et al. : Chondrosarcoma of the head and neck. Am J Surg 120: 4561970.

5) Krüger, E. : Problems concerning clinical and histologic diagnosis of oral Sarcomas. J dent Res 42 : 3541963.

6）佐藤研一，上田健夫：顎骨領域にお゙ける骨原性盾 場，1. 下顎骨・軟骨肉腫の 1 例. 日口外誌 21 : 1041975.

7) Lichtenstein, L. and Jaffe, H. L. : Chondrosarcoma of bone. Am J Path 19:553 1942.

8) Coventry, M. B. and Dahlin, D. C. : Osteogenic sarcoma. J Bone Joint Surg 39-A : 7411957.

9) Kragh, L. V. et al. : Osteogenic sarcoma of the jaws and facial bones. Am J Surg 96: 4961958.

10) Tiecke, R. W. : Oral Pathology. McGrow-Hill Book Company, New York, 1965, p 347.

11）谷口滋：軟骨肉腫の電子顕微鏡的研究. 千葉医 会誌 $43: 7681968$.

12) Erlandson, R. A. and Huvos, A. G. : Chondrosarcoma, A light and electron microscopic study. Cancer 34 : 16421974.

13）井村慎一，田中重男：軟骨腫および軟骨肉腫飞お ける核計測値と臨床像との関連. 臨整外 7:438 1972.

14) Godman, G. C. and Porter, K. R. : Chondrogenesis, studied with the electron microscope. J Biophys \& Biochem Cytol 8 : 7191960.

15) Matubas, V. J. et al. : Studies on ultrastructural identification and distribution of protein-polysaccharide in cartilage matrix. J Cell Biol 32 : 3651967.

16) Rhodin, J. A. G. : Histology, a Text and Atlas. Oxford University Press, New York, 1974, p. 177.

17) Silberberg, R. et al. : Life cycle of articular cartilage cells, An electron microscope study of the hip joint of the mouse. Am J Anat $114: 171964$.

18）張 洛善：变形性腅関節症の電子䫒微鏡的研究， 㮏蓋骨関節軟骨の变性像について。信州医誌 17 : 4771968.

19）小泉正明：軟骨の变性および老化闺する研究， その 1 関節軟骨の老化に関する電子顕微鏡的研 宪. 横浜医学 $15: 1841970$.

20) Silberberg, M. et al. : Ultrastructure of articular cartilage of mice treated with somatotrophin. J Bone Joint Surg 46-A : 7661964. 